\title{
The Role of Investment in Human Capital: Evolution Between Microeconomic and Macroeconomic Approach
}

\begin{abstract}
Babacar NDIAYE
Correspondence: Babacar NDIAYE, Associate Professor in economics, Faculty of Economics and Social Sciences, University Assane Seck of Ziguinchor, Laboratory of research in economics and social sciences, (LARSES), Senegal.
\end{abstract}

Received: January 8, 2018

doi:10.11114/aef.v5i2.2999

\author{
Accepted: January 29, $2018 \quad$ Available online: February 6, 2018
}

URL: https://doi.org/10.11114/aef.v5i2.2999

\begin{abstract}
It has been acknowledged for a long time that labour factor quality plays a significant role in the process of economic growth. The human capital theory that gained prominence notably with the works of Schultz (1961) and Becker (1964) underline that the knowledge gained by people is crucial to society, for education is an investment and a tool for improving productivity. The objective of this paper is to propose, in the neoclassical vision, a critical analysis of the developments and controversies surrounding human capital investment
\end{abstract}

Keywords: human capital, investment, growth

Classification JEL: E24, J24, O15

1. Introduction

Approximately a half-century ago, the work of Becker (1964) presented a very relevant analysis of human capital where the individual, located in the middle of the analysis, was not regarded any more as a simple ultimate consumer but rather perceived like a true producer who, by education and training acquires competences during his life. It is thus admitted since this date that the quality of the factor work plays a crucial role in the process of economic growth. Quite before, even if the concept of human capital was not the object of debates in the literature, Smith (1976) had shown that wealth of the individuals and the nations depends on the qualification level of the workers. The theory of the human capital which were also developed with the work of Schultz (1961) stresses that acquired knowledge by the individuals plays a crucial role in economic development. So the specialization of the labor and the division concept of the labor clarify the increase in the potential of production.

After several years of lapse of memory, the important question of the labor quality is again in the research center and in the economic debates. According to this theory, education is an investment because it is an instrument of improvement of the productivity. In order to justify this assumption, the theory takes into account the differences in remunerations between the workers. On the empirical level, Denison (1962) determined the main explanatory factors of economic growth in the United States by using the accounting of growth. He found a high value of the total productivity of the factors which he allotted to the improvement of the labour quality following the increase in the level of education. Thus, The neo-classic theories of economic growth (Solow, 1956); Swan, 1956) and those of the endogenous growth which were developed at the end of the years 1980 with Romer's work (1986) and Lucas (1988) provide models allowing to determine the implication of the human capital in the long run growth. It is in this perspective that the investment in the human capital is at the present time in the middle of the strategies put in work, in most countries to promote economic prosperity, employment and social cohesion. It is with these fundamental issues that this article is tackling with the controversies of the economic literature. A few months after Becker's death one of the founding fathers of the human capital theory, this paper makes the bet to carry out the prolongation of literature while being based on the developments of the neo-classic theories.

Although the approach of Becker, the theory of the human capital has two components : a theory of distribution of incomes and a theory of demand of education. On the basis of these two components, we present a critical reading of the neo-classic theories in the theory of rationality while proposing a possible reciprocal correlation of the components. So it is the productivity which provides the theoretical link between education and wages because the economist think in terms of maximized behaviors (Blöndal et al., 2001). Thus, the educational choice of the rational individual becomes a theory allowing to understand the expected motivations and effects. On this subject, Perruchet (2005) has the analogy 
between the investment in education and the investment in physical capital carried out by the companies in the optics which an immediate expenditure can generate for the future incomes. Also, the productivity of the old people or close to retirement decreases slightly in the course of time.

This paper is structured in the following way. The first section proposes an analysis of development and the controversies of the vision of the investment in human capital. The second section studies the approach of the growth by the human capital starting from the phenomenon of accumulation. The conclusion presents the main lessons and perspectives.

\section{The Investment in Human Capital in the Vision of Neo-Classic}

To understand what animates the rational individuals to continue a formation or a training in time, it is necessary to study the individual motivations and the collective motivations.

\subsection{Individual Motivations}

Traditionally, the micro economic approach is an integral part of the economic analysis owing to the fact that three fundamental assumptions are taken into account: the prevalence of the maximized behaviors, the existence of markets allowing to observe the individual behaviors and a relative stability, at the same time, time and the homogeneity enters between identical people of preferences. First of all, each individual seeks to maximize his satisfaction under budgetary constraint. One speaks then about rational individual making a temporal or intertemporal arbitration. Then, the individual is located at a market considered as the place, often abstracts, where confronts supply and demand to lead to exchanges characterized by market prices. Lastly, the individual preferences allowing to gather the agents in homogeneous groups from which the behaviors of arbitration will be studied. This is why Becker considers that "the combined assumption of maximized behavior, of market balance, and stable preferences, used in an intransigent and stoical way, form the heart of the economic approach" (Becker, 1976).

In the inter-temporal choices, the economic theory traditionally supposes that the agents gives less importance to their future utilities with their present utilities, i.e. the preference for the present. Even if this vision calls into question the design of inter generation solidarity, it considers that "the discounts rates on the future utilities are constant and fixed for each person, although they can vary from one person to another" (Becker, 1996). Thus, the individuals have the ability to better take into account in their present choices, their future utilities. When it is question of being formed, the individuals are ready to invest in their own training while giving up the additional profit of president utility.

Moreover, the investment in human capital is the cause of many forms of transfers between generations, in species or in kind, in the form of time, of cohabitation or even of assistance to housing. Wolff, (1998) considers for example that the parental assistances to young people address themselves in priority to the students in form of assistance to the continuations of their studies. In the same vein, this theory was continued by Attias-Donfut and Barnay, (2002) through an empirical study on the investment in human capital of three successive generations. They consider that the concept of investment in human capital the parents refers to the whole of the parental behaviors aiming at encouraging acquisition by their children of formations, qualifications, diplomas, likely to enrich their " human capital " , but also their social and professional competences. In their analysis, the transfer in human capital tends to produce sexed models while letting appear the existence of preferential links between fathers and sons and mothers and girls. Certainly in developing countries, mothers in general have the role to prepare and initiate their daughters with the family domestic tasks. It is then the mission of the female aptitudes of mothers as a girl. Therefore, the more the level of investment in human capital of the mother is high, the more the children will have great chance to be invested in human capital, and whatever the level of development of the economy in question. In the same vein, Becker considers that it is up to the individual to direct in the desired direction the state of his environment even if this latter plays on appearance of the individual. It is thus a question of highlighting the rules of decision. However, it is completely logical that the individuals try as well as possible to manage the resources at their disposal. Becker calls in this case "the instinctive economy of the man in the street ". In his vision," people who are not intellectuals are often surprised when they are told that this approach is discussed, because it seems obvious to them that the individuals seek to increase their welfare when they marry or they divorce." (Becker, 1993). So, he considers in his approach that the individual only objective is the maximization of his welfare expressed in the form of utility.

Several works, those of the Economic Cooperation organization and Development (OECD), show that in all countries, the investment in human capital goes with the concerned individuals, of sensitive improvement on the job market. From the individual point of view, there is a clear learning improvement income of households enabling him to satisfy his needs and to diversify his modes of consumption. Also, the rise of the income contributes to improve the purchasing power of consumers with a clear improvement in total demand. Blöndal et al. (2001) consider that education gets not only one initial advantage in terms of profits, but also a wage advantage which increases as the active life. Taking into account the gender, Blau and Kahn (2000) consider that in certain countries, there is a progression relatively weaker of the remuneration of women towards the end of their active life. 
In another approach, there is an analogy in which, it is possible to understand up to what point, the studies known as "long", like the doctorate, are regarded as an investment in human capital. Perruchet (2005) considers that so among variable objectives, usually privileged by the economists, appear wages in good place, the answer to this question in negative. There are other types of data allowing to understand the decision to continue the "long" studies. The incentive and the desincentive with employment depend on the economic environment in which the employees evolve. It will then belong to the individual to make an arbitration between the cost training and the expected profits after obtaining an employment. That is why, in Western countries, the trend more than secular watch a lengthening of the average duration of the schooling in order to contribute positively to the growth.

Beyond the individual motivation, the analysis of the investment in human capital fits in a collective vision near to the direction of the general interests.

\subsection{Collective Motivations}

The human capital prepares the individual to integrate the job market (OECD, 2012). This process is of individual interest, but of a collective interest too in the direction where the incomes drawn from employment benefit the community as a whole. Even in the Keynesian theory the financial resources of the state increase thanks to the tax income. Thus, the more the economic activity creates jobs, the more the own resource of the state, i.e. the taxes and the deductions at source, increase. The conjunction of these two resources allowing to establish a closer link with the job market, while permitting to increase the chances to find an employment, particularly by an adequacy between the supply of formation and the job application. Consequently, supply and demand of investment in human capital determine the training cost (Becker and Gheg, 1975).

Even if the theory of the tax income was the object of several controversies, Condorcet who was one of the first to develop the progressive theory of taxation on the income, had anticipated the principal well that most economists was to accept the personalization of the tax and social justice. It is in this perspective that the vision of the sociological approach seized the relationship between education and other social services owing to the fact that when certain parameters of the rules of the game are not defined and known for the benefit of all, the drawn profits from education will be a loss for the other components of the social life. Tiryakian (1960) considers under this angle the fragile wing of mass education in the under developed countries when this one goes against the values of social environment and cultural values fully accepted by the society.

Certainly, the individuals do not regard mainly education as a consumption bringing an immediate satisfaction to them, but rather as an investment. Moreover, the vision of Keynes is clear in this field: the renunciation of present consumption is conditioned with the only rise in the present capital in the future. In other words, the interest rate justifies the price of the renunciation of present consumption. Is it to say that education is comparable to savings? For sure education would have common characteristics with physical capital. One can thus assimilate it as an expenditure present carried out for a future output. From this point of view, it should be noticed that that the concept of human capital can be integrated in the growth. Indeed, the two principal inputs of the production (labour and capital) clearly do not allow to give an account of the observed growth. With a considerable share of growth which is not explained by these factors, the quality of the factors work, in terms of service or real production, is regarded as being one of the sources of growth.

\section{The Investment in Human Capital Like Victor of Growth}

The growth by the investment in human capital consists in proposing a new approach in which this one constitutes a factors allowing to determine an optimal social output and prospects for employment on the job market.

\subsection{Knowledge Like Lever of Growth}

The question of the impact of the investment in human capital about the growth also refers to the canonical models of endogenous growth, among which the model of growth by externality on the stock of capital (Romer, 1986), by accumulation of human capital (Lucas, 1988), by increase in the diversity of the capital goods (Romer, 1990), by increase in the quality of goods in a process of creative destruction (Aghion and Howitt, 1992) and finally by the role of the public expenditure (Barro, 1990). In this second section, one is interested particularly in the canonical models .of endogenous growth by accumulation of human capital owing to the fact that the human capital occupies an important place in the growth of the developed economies (Basdevant, 2002).

In two famous articles, Lucas (1988), then Nyssen (2000) show that the growth of a model of the Solow's type is maintained thanks to a process with constant outputs. These works examine the behavior of an endogenous model of growth with innovation in which the choices of the agents consist in at every moment distributing the available human capital between researches development (R \& D) and the production. Beyond the commercial, financial and strategic advantages, the $\mathrm{R} \& \mathrm{D}$ have also important issues as regards the production.

Nowadays, this approach requires too a good comprehension of the role of the individual as an actor of development 
through technical progress. In his work, Capitalism, Socialism and democracy, Schumpeter (1942) consider that industrial progressing the key of change. Thus, the author of the theory of the impulse by the creative destruction, key concept of the growth, supports that "the fundamental impulse which puts and maintains in movement the capitalist machine is printed by the new type's objects of consumption, the new method of production and transport, the new markets, the new types of industrial engineering-all elements created by the capitalist initiative" (Schumpeter, 1942). The whole of these criteria, making it possible to high light technical progress resulting from a training leading to qualification, positions the individual as a main actor of development.

However, when the supply of formation is inadequacy with the application for a job, the added value created permits to register the economic dynamic towards a balanced job market. Education and training constitute an investment of which the individual expects a certain return.

The idea according to which the growth rises from, partly, was developed by Arrow (1962). Regarded as one of the founders of the neo-classic school, he sought to determine the explanations of growth starting from knowledge. He develops the idea according to which the effectiveness of the factors of production depends on " the training by the practice" (learning by doing).

This is justified by the fact that he says" the assumption that the technical changes can in general be given by the experiment, and that it is the production activity which makes emerge the problems for which adequate answers can be selected in the course of time. (...). This allows the assumption and its consequences more accessible to a confrontation obviously empirical. “(Arrow, 1962).

In addition, the model suggested by Arrow does not match with the human capital, but passes in a more traditional way by taking into account machines like lever to incorporate innovations. While carrying out a causal analysis, it is possible to consider that the machine is at the origin of human work.

However, it is difficult to measure the share or the impact of the human capital in the process of economic growth. Berthélémy et al. ( 1996) tried, nevertheless, to solve the enigma by explicitly integrating the human capital in the technological elements. Other studies show that human capital is a factor of development by the positive externalities of developed countries for the benefit of developing countries (Coe et al., 1991; Temple, 1999).

It is clear that in its role of distribution, the state aims at redistributing part of the rich household incomes to the profit of the poor households, thus allowing the man access to education. The finality of this policy appears effective, but its application and transmission systems in the cycle of consumption of high incomes impose the existence of harmful effects on the growth because that discourages the private sector investment. Indeed, the policy of social justice in terms of redistribution is not compatible with the objectives of effectiveness of investment policies in human capital. Thus, a rise of the tax rates on the high incomes goes with a discouraging investment ( in physical capital as in human capital) since the output of educative investment is a function of the earned income. Therefore, the model of Barro (1990) is pressed on the curve of Laffer growth and the relation out of bell between the tax rate and the growth to show that even if the rise of the taxes reduces the clear marginal productivity of the private capital, i.e. incitement to invest, then the increase in the additional receipts allowing to finance the productive expenditure have a more important effect on the long-term growth ( Minea and Villieu, 2008). In this case, the investment in human capital is regarded as a productive public expenditure because it contributes to the growth. Thus, the education system must be correlated with the needs of specific sectors allowing to promote the economic growth.

From now on, the development of the theory of the human capital made "obsolete" the initial models found on the exogenic growth. The traditional model of Solow did not explain clearly the growth because considering that technical progress is the only factor allowing the growth to continue. Keeping the endogenous theory of growth, technical progress is a consequence whose causes are to be searched among several factors which contribute to its realization. Guellec and Ralle (1993) consider that growth is thus comparable with a self maintained phenomenon undertook by accumulation of four principal factors: technology, the physical capital, the human capital and the public capital. Being given that these four factors have a common denominator which is the investment, their impact on the growth depends on the arbitration made with the taking into account of the whole of macro-economic variables which influence the total request. The endogenous theory of growth is thus founded in taking into account of these factors while specifying for each one of them the essential criteria playing the growth positively. For example, concerning the human capital these criteria are: the level of schooling, the qualification and the health status of the individual and indicators of human development. For the technical, the essential criteria are: the R \& D, the innovation and technology. The whole of these factors contribute to emergence by the human capital thanks to convergence towards an effective path of technology.

\subsection{The Human Capital Like Factor of Convergence}

Since the division of the labor of Smith until accumulation of human capital of Lucas (1988) via the theory of the productivity of Malthus, it is recognized that the origin of the growth results from the bases of the human capital. The 
evolution of these theory shows that the profits of the production or the productive surplus must be reinvested to maintain a level of satisfied production compared to the demand.

The integration of the human capital in the production process favors the productivity on the one hand and the growth of gross domestic product (GDP) on the other hand. This process accelerates the mechanism of correction between developed countries by the developing countries. The fundamental question on this level relates to the financing of the human capital. Beyond the public intervention to correct the imperfections of the market, the private financing is an important resource in the process of correction of the economies. The models of Solow (1956) and Swan (1956) offer a dynamic frame work in which, the objective is to characterize the path of stationary growth, i.e. that where the variables of growth per capita (production, the capital and released savings are constant.

In addition, it is recommended the need for the intervention of the state in the implementation of the policies of revival. It allows to pass from a situation of under-employment characterized by chronic unemployment to a situation of full employment whose theoretical design is in contradiction with economic realities. In this perspective to call into question this vision, the assumption of hysteresis consists in supporting that the unemployment rate today is all the more important as it was yesterday. Such an assumption implies that the real wages evolve according to the variation of unemployment and not of its level. In other words, the economic conjuncture determines the purchasing power of households whatever their preference in terms of consumer goods. The effects of hysteresis rise from a macroeconomic framing from the system in which the current variables and those of the past influence the evolution of economic system. Phelps (1972) proposed an application of this notion to the theory of unemployment. There are after that several economists such as Blanchard and Summers (1986) consider that "speak of hysteresis as regards unemployment means that the value of natural unemployment rate is function of that of the unemployment rate observed in the past".

\section{Conclusion}

On the basis of the principle that the human capital is regarded as an immaterial good allowing to make the productivity more effective and to promote competences, its accumulation allows productivity gains favorable to the growth and employment. In so far as the education process is inconformity with that defined by Lucas, i.e. the possibility for agents of improving their qualification thanks to a process with increasing outputs, then education is regarded as one of the engines of the growth in the long run. This consequence rise owing to the fact that there is an arbitration between the time of individual savings and the time of unpaid wok devoted to education and allowing to have a level of more important wages in the future.

However, there are weaknesses in the manner of analyzing education like an essential condition to reach development. In certain economies, a constant improvement of the level of education is a requirement but nonsufficient for the economic growth (Booth, 1998).

\section{References}

Aghion, P., \& Howitt, P. (1992). A Model of growth through Creative Destruction, Econometrica, 60(2), 323-351. https://doi.org/10.2307/2951599

Arrow, K. J. (1962). The economic implications of learning by doing, The Review of Economic Studies, Oxford Journal, 29(3), 155-173.

Attias, D. C., \& Barnay, T. (2002). Investissement en capital humain en fonction des sexes, Revue économique, 53(4), 839-861.

Barro, R. J. (1990). Governement Spending in a Simple Model of Economic Growth, Journal of Political Economy, 98, 103-125. https://doi.org/10.1086/261726

Basdevant, O. (2002). Croissance, R\&D et formation: Une revue de la littérature, Revue d'économie politique, 112, 173-195. https://doi.org/10.3917/redp.122.0173

Becker, G. S. (1964, 1993, 3rd ed.). Human Capital: A Theoretical and Empirical Analysis, with Special Reference to Education. Chicago, University of Chicago Press.

Becker, G. S. (1976). The Economic Approach to Human Behavior, University of Chicago Press.

Becker, G. S. (1996). Accounting for Tastes, Harvard University Press.

Becker, G. S., \& Ghez, G. (1975). The Allocation of Time and Goods Over the Life Cycle. New York, Columbia University Press.

Berthélémy, J. C., Dessus, S., \& Varoudakis, A. (1997). Capital humain et croissance: le rôle du régime commercial, Revue économique, 48(3), 419-428.

Blanchard, O., \& Summers, L. (1986). A Hysteresis and the European Unemployment Problem, @NBER Macro Annual. 
https://doi.org/10.3386/w1950

Blau, F., \& Kahn, L. (2000). Gender differences in pay, Journal of Economic Perspectives, 14, 74-99. https://doi.org/10.1257/jep.14.4.75

Blöndal, S., Fied, S., Girouard, N., \& Wagner, A. (2001). Investment in human capital through postcompulsory education and training: Selected efficiency and equity aspects, $O C D E$, Département des affaires économiques.

Booth, A. (1998). Initial Conditions and Miraculous Growth: Why is South East Asia different from Taiwan and South Korea?, mimeo, University of London, May.

Coe, D., Helpman, E., \& Summers, L. (1991). Equipment investment and economic growth, Quarterly Journal of Economics, 106, 445-502. https://doi.org/10.2307/2937944

Denison, E. F. (1962). The Sources of Economic Growth in the United States and the Alternatives Before Us, New York: Committee for Economic Development.

Guellec, D., \& Ralle, P. (1996). Les nouvelles théories de la croissance, La Découverte, Repères.

Lucas, R. (1988). On the Mechanics of Economic Development, Journal of Monetary Economics, 22, 3-42. https://doi.org/10.1016/0304-3932(88)90168-7

Nyssen, J. (2000). Croissance, innovation et éducation, Annales d'économie et de statistique, 57, 125-157. https://doi.org/10.2307/20076217

OCDE. (2001), Projet de l'OCDE sur la croissance, Paris.

OCDE. (2012). Quels sont les avantages sociaux de l'éducation?, dans Regards sur l'éducation 2012: Panorama, Éditions OCDE.

Perruchet, A. (2005). Investir dans une thèse : capital humain ou capital culturel? Thèse de doctorat, IREDU, UMR CNRS 5192.

Phelps, E. S. (1972). Inflation Policy and Unemployment Theory, New York: Norton.

Romer, P. (1986). Increasing Returns and Long Run Growth, Journal of Political Economy, 94(5), 1002-1037. https://doi.org/10.1086/261420

Romer, P. (1990). Endogenous Technical Change, Journal of Political Economy, 98(5), 71-102. https://doi.org/10.1086/261725

Schultz, T. W. (1961). Investment in human capital, The American Economic Review, 51(1), 1-17.

Schumpeter, J. (1942). Capitalisme, socialisme et démocratie : La doctrine marxiste. Le capitalisme peut-il survivre? Le socialisme peut-il fonctionner? Traduction française de Gaël Fain, 1942. (Paris: Petite bibliothèque Payot, no 55, texte de la 2e édition, 1946. Paris: 1965).

Smith, A. (1776). Recherche sur la nature et les causes de la Richesse des Nations, I(II) (réimpression, GF-Flammarion, 1991).

Solow, R. (1956). A contribution to the theory of economic growth, Quarterly Journal of Economics, 70(1), 65-94. https://doi.org/10.2307/1884513

Swan, T. (1956). Economic growth and capital accumulation, Economics Record, 32(2), 334-361. https://doi.org/10.1111/j.1475-4932.1956.tb00434.x

Temple, J. (1999). The new growth evidence, Journal of Economic Literature, 37, 112-156. https://doi.org/10.1257/jel.37.1.112

Tiryakian, A. E. (1960). Quelques aspects négatifs de l'éducation de masse dans les pays sous-développés. In: Tiers-Monde, 1(1-2), 161-173. https://doi.org/10.3406/tiers.1960.1190

Wolff, F. C. (1998). La nature des transferts inter vivos en France: investissements humains, aides financières et transmissions du patrimoine, Economie et prévisions, 135, 1-27.

\section{Copyrights}

Copyright for this article is retained by the author(s), with first publication rights granted to the journal.

This is an open-access article distributed under the terms and conditions of the Creative Commons Attribution license which permits unrestricted use, distribution, and reproduction in any medium, provided the original work is properly cited. 